NOTE

\title{
Fate of copepod faecal pellets and the role of Oithona spp.
}

\author{
Marit Reigstad*, Christian Wexels Riser, Camilla Svensen \\ Norwegian College of Fishery Science, University of Tromsø, 9037 Tromsø, Norway
}

\begin{abstract}
Because the downward flux of zooplankton faecal pellets (FP) measured in sediment traps is typically lower than FP production in overlaying waters, it is inferred that FP are recycled. One suggested explanation for low export fluxes of FP is retention through processes such as FP ingestion (coprophagy) and FP fragmentation (coprorhexy). It has become accepted that the globally important cyclopoid copepod Oithona spp. are one of the main organisms causing high retention of copepod FP, however, the experimental evidence supporting this hypothesis is limited. We conducted 3 experiments to test whether the raptorial feeding Oithona spp. removed sinking FP material produced by Calanus finmarchicus either by grazing or fragmentation. No such evidence was found. We therefore suggest that alternative explanations for pellet recycling should be sought. We believe that Oithona spp. may be indicator species for a 'retention ecosystem', but they are probably not the single factor explaining FP retention in the world oceans.
\end{abstract}

KEY WORDS: Faecal pellet · Faecal pellet retention · Oithona $\cdot$ Coprophagy $\cdot$ Calanus finmarchicus · Faecal pellet fragmentation

Resale or republication not permitted without written consent of the publisher

\section{INTRODUCTION}

The downward flux of intact faecal pellets (FP) measured in sediment traps is only a fraction of what is produced in the overlaying waters, both in coastal and open ocean environments (Small et al. 1987, Dam et al. 1995, Urban-Rich et al. 1999, Viitasalo et al. 1999, Wexels Riser et al. 2002, Sampei et al. 2004). The fate of FP and their role in the marine carbon budget has therefore frequently been debated. One suggested explanation for low export fluxes of FP is retention through processes such as coprophagy and coprorhexy (Smetacek 1980, Sasaki \& Nishizawa 1981). Both processes imply decreasing FP sinking fluxes, as FP are either consumed (coprophagy) or modified (coprorhexy/coprochaly) by zooplankton (Lampitt et al. 1990, Noji et al. 1991). When FP are fragmented, sinking velocity decreases and the fragments contribute to the pool of suspended detritus (Smetacek 1980) and regenerated food web (Wassmann 1998).
Some zooplankton species are assumed to play key roles in the regulation of carbon export from the euphotic zone, and the most frequently cited species in this respect is the cyclopoid copepod Oithona spp. (Lampitt \& Gamble 1982, Gonzáles \& Smetacek 1994, Kiørboe \& Visser 1999, Suzuki et al. 2003, Svensen \& Nejstgaard 2003). This is mainly based on their raptorial feeding behaviour and preference for larger and moving prey particles (Lampitt 1978, Drits \& Semenova 1984, Gonzáles \& Smetacek 1994, Svensen \& Kiørboe 2000, Paffenhöfer \& Mazzocchi 2002). Both swimming prey and sinking FP produce a hydromechanical signal that can be detected by Oithona spp. (Svensen \& Kiørboe 2000), potentially leading to attack and ingestion of the prey particle. The ubiquitous abundance and broad geographical distribution of Oithona spp. (Paffenhöfer 1993, Turner 2004) also suggests an opportunistic strategy, feeding on whatever is present. It has been suggested that populations of Oithona spp. may act as a 'coprophagous filter' (Gonzáles \& Sme- 
tacek 1994). Pulses of sedimented FP would then be a result of 'leaks' in the 'filter' that could be caused by patchiness in horizontal distribution or local decimation of the scavengers by predators' (e.g. Gonzáles \& Smetacek 1994).

Experiments have demonstrated that Oithona similis may feed on pellets produced by Calanus glacialis, C. finmarchicus and Temora longicornis (Gonzáles \& Smetacek 1994). However, these experiments were conducted in upright bottles where FP was sinking and $O$. similis were reported to graze FP from the bottom of the bottles. Based on the knowledge that Oithona spp. are raptorial feeders, we wanted to investigate their impact on FP in suspension. Furthermore, there are several pieces of evidence on significant FP retention from coastal regions of northern Norway and the Barents Sea (Urban-Rich et al. 1999, Wexels Riser et al. 2002), but we are not aware of any attempts to experimentally address the topic in this region. As Oithona spp. periodically are among the most abundant copepods in this region (Pasternak et al. 2000, Arashkevich et al. 2002), we therefore designed experiments with the purpose of testing the hypothesis that Oithona spp. are consuming FP produced by $C$. finmarchicus (hereafter referred to as Oithona and Calanus).

\section{MATERIALS AND METHODS}

Copepods and food. The fate of FP from the calanoid copepod Calanus was investigated during 3 experiments, 16 to 24 March 2004. Mesozooplankton was collected during a pre-bloom condition in the sea close to Tromsø, Norway $\left(69^{\circ} 40^{\prime} \mathrm{N}, 18^{\circ} 55^{\prime} \mathrm{E}\right)$ ahead of each experiment. A WP-2 net (90 $\mu \mathrm{m}$ mesh size) with large cod-end was used for gentle sampling. The content was diluted at sea and acclimatised overnight in a cold room $\left(8^{\circ} \mathrm{C}\right)$ in an aerated tank with additional food. Active female Calanus and Oithona females $(O$. similis dominated with a few $O$. atlantica) without any visible damage were selected for the experiments.

Thalassiosira weissflogi from an exponentially growing culture dominated by single cells (diameter = $10 \mu \mathrm{m}$ ) and a few shorter chains was used as food for Calanus to produce FP in all experiments. Algae were grown in F/2 medium (Guillard \& Ryther 1962) in a 14:10 $\mathrm{h}$ day:night light regime (40 to $50 \mu \mathrm{E}, 8^{\circ} \mathrm{C}$ ) approximating the natural conditions in the region. $T$. weissflogi was selected as food to enhance the potential FP consumption by Oithona since this diatom is assumed to provide good food for Calanus and unsuitable food for Oithona, which prefer motile prey and larger cell sizes (Svensen \& Kiørboe 2000). Algal concentrations in the incubation water were calculated from cell counts using an inverted microscope, and food concentrations of 0.5 to $2.0 \mathrm{mg} \mathrm{C}^{-1}$ were offered (Table 1). The experiments were run in a temperature controlled room $\left(8^{\circ} \mathrm{C}\right)$ in dim light. Copepods were incubated in $1000 \mathrm{ml}$ bottles (sealed without bubbles) on a plankton wheel (1 rpm) to allow the FP to be suspended, thereby mimicking the natural feeding conditions of Oithona. Visual inspection showed that pellets were kept in suspension during the experiments.

We performed 3 experiments to investigate the effect of Oithona on FP produced by Calanus. Since stable FP production rates were crucial for our hypothesis, we first investigated the sensitivity of FP production rates to the copepod densities in Expt 1. This was to minimize the variability between replicates and ensure that indi-

Table 1. Experimental set up for Expts 1 to 3. Number of incubated copepods (Calanus finmarchicus female (Cf) and Oithona spp. female (O)) for treatment and control bottles is given with number of replicates (n). Incubation time is given in $h$, and food

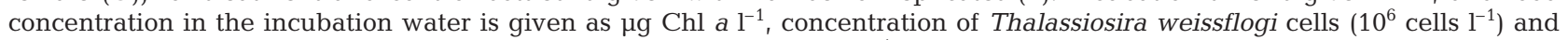
$\mathrm{C}$ content $\left(\mu \mathrm{g} \mathrm{C}^{-1}\right)$

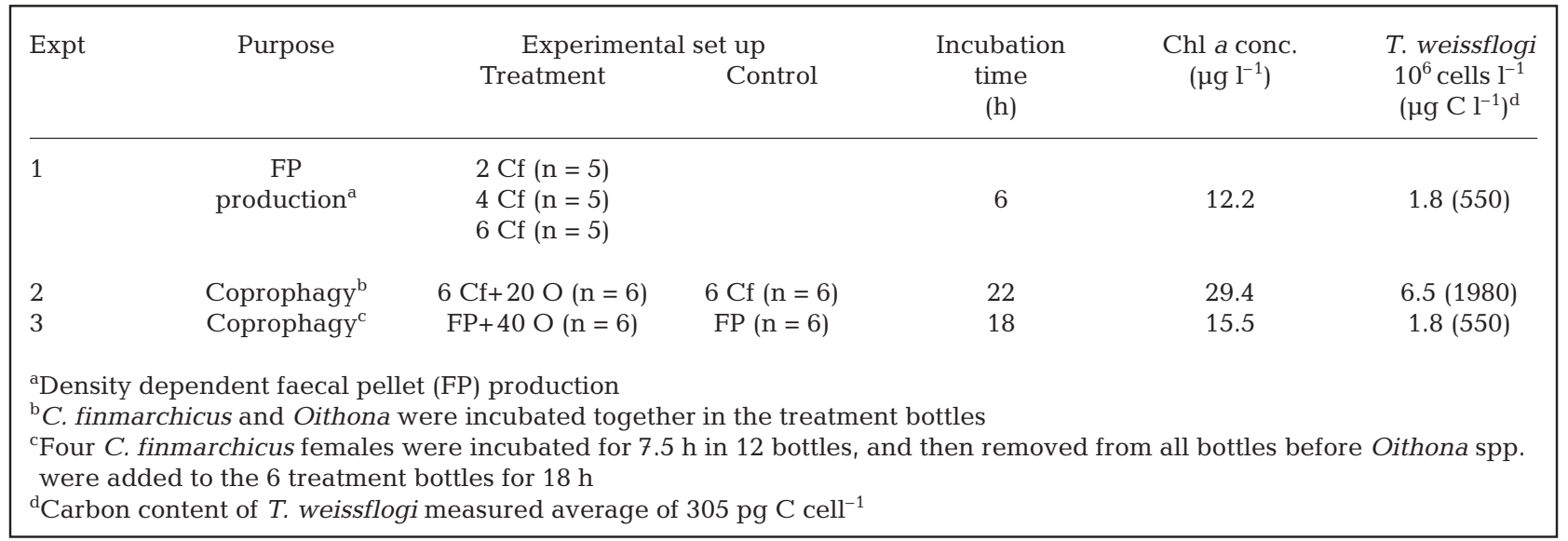


vidually variable FP production rates did not affect the interpretation of the results. The potential removal of Calanus FP by Oithona was addressed using 2 different experimental set ups (Expts 2 and 3). In Expt 2 Calanus and Oithona were incubated in the same bottles, while in Expt 3 the Calanus were removed after FP production in order to eliminate potential disturbance of Oithona from the swimming and grazing Calanus.

Expt 1. We used 3 densities of Calanus, 2, 4 and 6 ind. bottle ${ }^{-1}$ to test whether FP production was affected by copepod density. Each copepod concentration was incubated in 5 replicates. Food was offered at a high and non-limiting concentration, $\sim 550 \mu \mathrm{g} \mathrm{Cl}^{-1}$, corresponding to $2 \times 10^{6}$ Thalassiosira weissflogi cells $\mathrm{l}^{-1}$ (Table 1). After $6 \mathrm{~h}$ incubation on a plankton wheel $(1 \mathrm{rpm})$, the contents of each bottle were gently sieved through a $20 \mu \mathrm{m}$ Nitex mesh, fixed with buffered formalin ( $2 \%$ final concentration) and the FP were then analysed. FP fragmentation caused by Calanus through active grazing, destruction or by passive mechanical disruption was also recorded.

Expt 2. We incubated 6 Calanus and 20 Oithona together in 11 bottles in 6 replicates for $22 \mathrm{~h}$ (Table 1) on a rotating plankton wheel. The control consisted of 6 bottles containing only Calanus. Food was offered in non-limiting concentrations corresponding to $\sim 2000 \mu \mathrm{g} \mathrm{C} \mathrm{l}^{-1}$ (Table 1). After incubation the animals were checked for viability and the total contents of the bottle were sieved through a $20 \mu \mathrm{m}$ Nitex mesh to retain FP. The FP removal by Oithona was calculated from the difference in FP biomass in treatment and control bottles.

Expt 3. We incubated 4 Calanus in $1 \mathrm{l}$ bottles with food concentrations corresponding to $550 \mathrm{\mu g} \mathrm{C} \mathrm{l}^{-1}$ to produce pellets. After $7.5 \mathrm{~h}$ the Calanus were gently removed using a pipette and 40 Oithona bottle ${ }^{-1}$ were added (6 replicates). No Oithona were added to the 6 controls, leaving only pellets in these bottles. The bottles with pellets and Oithona and the controls with only FP were then incubated for another $18 \mathrm{~h}$ on a slowly rotating plankton wheel $(1 \mathrm{rpm})$. After incubation the animals were checked for viability and the total contents of the bottles were sieved through a $20 \mu \mathrm{m}$ Nitex mesh to retain FP.

Chlorophyll $a$ and carbon determinations. $\mathrm{Chl} a$ concentrations in the incubation water were measured on a Turner Designs model 10-AU fluorometer after filtration $(3 \times 50 \mathrm{ml})$ on GF/F filter and extraction in $100 \%$ methanol overnight (Holm-Hansen \& Riemann 1978). For POC analyses, incubation water was filtered on pre-burned GF/F filters $(3 \times 100 \mathrm{ml})$, frozen $\left(-20^{\circ} \mathrm{C}\right)$, and analysed with a Leeman Lab 440 elemental analyser after fuming with $\mathrm{HCl}$ to remove inorganic carbon. Carbon content was also determined for Calanus females $(\mathrm{n}=3)$ and FP (Table 2).
Table 2. Average width, volume and carbon content of intact faecal pellets (FP) produced by Calanus finmarchicus females in the experiment. Dry weight $(\mathrm{dw})$, carbon $(\mathrm{C})$, nitrogen $(\mathrm{N})$ and $\mathrm{C}: \mathrm{N}$ ratio of $\mathrm{C}$. finmarchicus females from a North

Norwegian fjord, March 2004. Variation is given as \pm SD

\begin{tabular}{|c|c|}
\hline Faecal pellets & \\
\hline Width $(\mu \mathrm{m})$ & $61 \pm 8$ \\
\hline Volume $\left(10^{4} \mu \mathrm{m}^{3}\right)$ & $198 \pm 95$ \\
\hline Carbon content $\left(\mu \mathrm{g} \mathrm{C} \mathrm{mm^{-3 } )}\right.$ & 80.3 \\
\hline Carbon content (ng C pellet ${ }^{-1}$ ) & 159 \\
\hline Calanus finmarchicus females & \\
\hline $\mathrm{dw}\left(\mu \mathrm{g}\right.$ ind.$\left.^{-1}\right)$ & $262 \pm 31$ \\
\hline$\% C\left(\mu g d^{-1}\right)$ & $37 \pm 1$ \\
\hline$\% \mathrm{~N}\left(\mu \mathrm{g} \mathrm{dw^{-1 }}\right)$ & $7 \pm 0$ \\
\hline C:N (a:a) & $6 \pm 0$ \\
\hline
\end{tabular}

FP analyses. To obtain the best quantitative measure of the FP, volume was determined for all pellets. Entire samples were counted by the Utermöhl technique (Utermöhl 1931), using an inverted microscope (100× magnification) equipped with measuring ocular. The FP were sized (length and width measured) and categorised as a whole pellet, end piece or mid part. Total FP volume could then be calculated assuming a cylindrical shape (Edler 1979). The total pellet number in each bottle was calculated by adding up the whole pellets and the number of end pieces divided by 2. Mid parts contributed to FP volume, but not the number of pellets.

A FP carbon conversion factor was obtained by individually picking intact FP produced by Calanus during a $21.5 \mathrm{~h}$ incubation (conditions similar to Expt 2, Table 1). The pellets were rinsed twice in $0.4 \mu \mathrm{m}$ filtered seawater, filtered onto a pre-burned GF/F filter in 3 replicates $(100,113$ and $125 \mathrm{FP}$, respectively) and frozen $\left(-20^{\circ} \mathrm{C}\right)$ until analysed. The average size of all unbroken FP $(\mathrm{n}=917)$ produced by Calanus females during all experiments was used to calculate the carbon/volume ratio giving a $\mathrm{C}$ conversion factor of $80.34 \mu \mathrm{g} \mathrm{C} \mathrm{mm}{ }^{-3}$ (Table 2). Pellet production rates were calculated in terms of numbers (\#FP ind. ${ }^{-1} \mathrm{~d}^{-1}$ ) and carbon ( $\mu \mathrm{g} \mathrm{C}$ ind..$^{-1} \mathrm{~d}^{-1}$ ).

A 1-way ANOVA and $t$-test were run at the $95 \%$ level using Excel $\mathrm{X}$ to test the results for statistical significance.

\section{RESULTS AND DISCUSSION}

\section{Did Oithona graze copepod FP?}

No evidence was found that Oithona removed FP material in any of the experiments. In Expts 2 and 3 we evaluated the potential of 2 Oithona concentrations to remove Calanus FP (Fig. 1). In Expt 2, 20 Oithona were incubated with 6 Calanus. The total FP carbon or aver- 


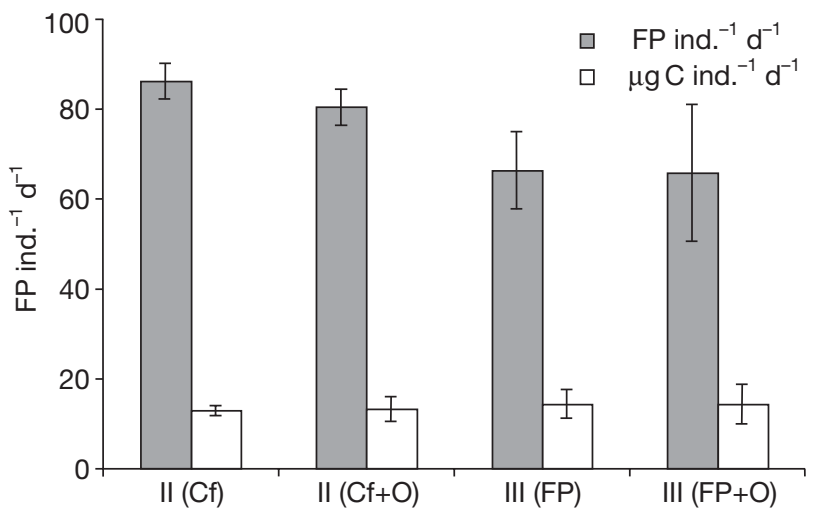

Fig. 1. Faecal pellet (FP) production in bottles with and without Oithona $(\mathrm{O})$ in Expts 2 and 3 presented in terms of numbers and carbon. Bars represent $95 \%$ CI. FP were produced by Calanus finmarchicus (Cf) females

age number of Calanus pellets recovered after incubation in the bottles with Oithona did not differ significantly from the controls with no Oithona (2-tailed t-test; $\mathrm{p}=0.82$ and $\mathrm{p}=0.42$ for total carbon and number of FP, respectively) (Fig. 1). In Expt 3, 40 individuals of Oithona per bottle were offered 78 to 105 FP. Even with this high concentration of Oithona there were no differences between treatment and control bottles. This complete lack of FP removal by Oithona was in contrast to previous experiments (Gonzales \& Smetacek 1994).

A daily food requirement of Oithona similis (160 ng C ind $.^{-1} \mathrm{~d}^{-1}, 19$ to $21^{\circ} \mathrm{C}$, Nakamura \& Turner 1997) corresponds to the carbon content of 1 average sized FP from a Calanus female in this experiment (159 ng C pellet $^{-1}$ ). The Oithona females should thus be able to consume $40 \%$ of the present pellets to meet their daily C needs. If Oithona consumed FP, either through ingesting whole pellets or more likely by eating parts of the FP, this should have been detected as a reduced FP volume in the bottles with Oithona. This was not the case.

Stable FP production is of crucial importance when studying FP removal. Calanus demonstrated a relatively high and stable FP production of 4 to $5 \mathrm{FP} \mathrm{h}^{-1}$ in Expt 1 (Fig. 2), and the number of pellets produced per female and the pellet biovolume egested did not differ significantly as a result of changing Calanus density (1-way ANOVA; $F=3.69, \mathrm{p}=0.059$ ). Generally, high FP fragmentation was observed during the experiments ( 23 to $40 \%$ of the pellets counted). The presence of 20 or 40 Oithona or the concentration of 2,4 or 6 Calanus did not increase or change the fraction of broken/fragmented FP (2-tailed $t$-test; $p$ > 0.05). Any minor increase in FP volume caused by the fragmentation would thus be similar for experimental and control

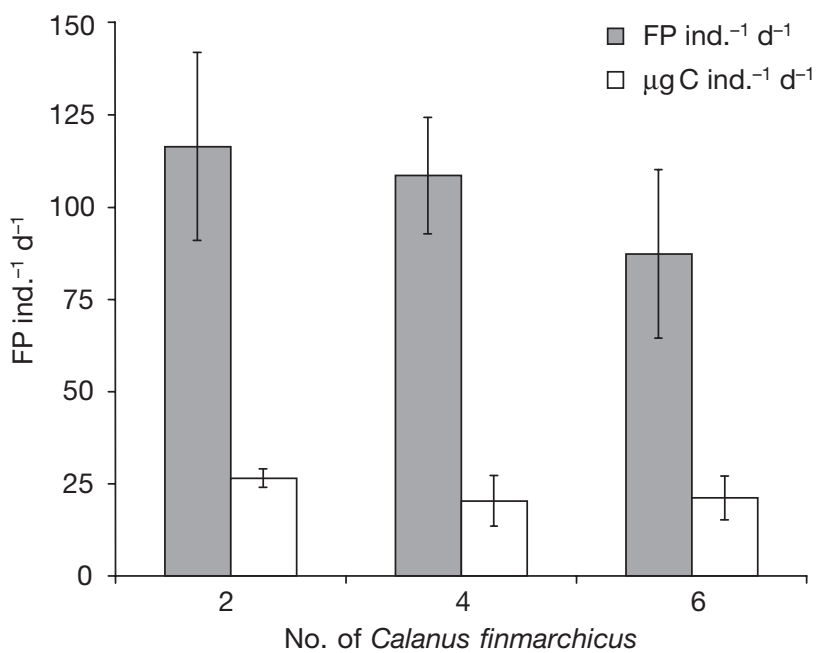

Fig. 2. Density-dependent faecal pellet (FP) production by Calanus finmarchicus in Expt 1. FP production presented in terms of numbers and carbon. Bars represent $95 \%$ CI

bottles, and would not influence our results and conclusions. A likely explanation for the high fragmentation is the combination of high food concentrations and small food particles used in the experiments which can result in less dense and faster degrading FP (Hansen et al. 1996, Feinberg \& Dam 1998).

We argue that the lack of FP removal by Oithona was not a result of inappropriate experimental methods. A plankton wheel was used to ensure that the FP were suspended. The suspended and sinking FP were supposed to create hydromechanical signals and increase the detection by the raptorial feeding Oithona. Individuals of Oithona chosen were all active before and after the experiment, and most of them were carrying egg sacs when incubated, indicating active feeding mode.

\section{Fate of FP in the field}

The resulting lack of any indication of Oithona spp. feeding on or increasing fragmentation of the Calanus FP was surprising. Copepod concentrations used were all within the range observed in the field (Halvorsen \& Tande 1999, Turner 2004) and so were the diatom concentrations (Eilertsen et al. 1981) and the FP production rates (Urban-Rich et al. 1999, Wexels Riser et al. 2002). We argue that these results imply that there is a need for further investigation on the FP retention mechanisms. Our results do not prove that Oithona do not feed on FP, but they demonstrate that they do not always feed on FP when present. Temperature dependent respiration for $O$. similis, measured by Castellani et al. (2005), suggests low energy demand at low temperatures, and they refer to in situ ingestion rates of 5 
to $327 \%$ body carbon $\mathrm{d}^{-1}$ from the cold sub-Antarctic regions ( -1 to $6.5^{\circ} \mathrm{C}$, Castellani et al. 2005, and references therein). For a female $O$. similis of $0.6 \mu \mathrm{g} \mathrm{C}$ ind. ${ }^{-1}$ (Kiørboe \& Sabatini 1994) the corresponding daily consumption is 0.03 to $1.96 \mu \mathrm{g} \mathrm{C}$ ind. ${ }^{-1}$ or 0.2 to 12.3 Calanus FP. High variability in the retention potential by Oithona is therefore likely, especially in cold regions. Hence, predicting FP removal from Oithona abundance is obviously too simple. To explain the strong retention that evidently takes place in the field, also in low temperature regions (Gonzáles et al. 1994, Wassmann 1998, Urban-Rich et al. 1999, Viitasalo et al. 1999, Wexels Riser et al. 2001, 2002, Sampei et al. 2004), further attention is needed to search for alternative mechanisms and organisms that may shed light on the high retention of copepod FP reported.

Organisms other than Oithona have been suggested or shown to influence the fate of FP. High retention of FP has also been described where the abundance of Oithona have been low - in these cases larger mesozooplankton have been suggested to play a significant role (Urban-Rich et al. 1999, Sampei et al. 2004). Calanus helgolandicus (Paffenhöfer \& Strickland 1970), Calanus nauplii (Green et al. 1992) and heterotrophic dinoflagellates (Kiørboe 2003) have all been shown to ingest FP. Mechanical destruction (coprorhexy) of FP (Noji et al. 1991) or degradation caused by wind induced turbulence (Viitasalo et al. 1999) are also described or suggested to fragment pellets and increase degradation and retention. Variability in the robustness of the FP based on diet or food concentration is another suggested mechanism (Hansen et al. 1996).

During periods or events when the food items cause more fragile pellets and reduced FP export, disintegration might be the most prominent retention mechanism. Our results indicate that this can also take place in early spring when small diatoms dominate. There is obviously a need for more work on how different food compositions influence the fate of zooplankton pellets. It is also necessary to investigate how different species and stages of zooplankton and physical factors contribute to retention. FP production experiments and simultaneous sedimentation measurements from contrasting regions such as off- versus on-shelf systems (Wexels Riser et al. 2001) and Atlantic versus Arctic regions of the Barents Sea (Wexels Riser et al. 2002) have revealed higher versus lower retention areas with regard to copepod FP. Some ecosystems are more retentive than others (Wassmann 1998), and Oithona might be an indicator species for high retention ecosystems without being the only causing agent in the system. It is therefore important that the coincidence of high Oithona abundance and high FP retention is not interpreted as an inevitable cause and effect mechanism.
Acknowledgements. We are grateful to H. Hodal, L. Seuthe and E. Halsnes on RV 'Hyas' for assistance in field. We thank U. Tillmann at AWI, Bremerhaven, for providing the diatom culture. Four anonymous referees are acknowledged for constructive comments. M.R. and C.W.R. were financed by the Norwegian Research Council through the CABANERA project, NFR Project no. 155936/700. C.S. received financial support by the European commission through the project FATE (contract no EVK3-CT01-00055) as a part of the ECEUROHAB cluster.

\section{LITERATURE CITED}

Arashkevich E, Wassmann P, Pasternak A, Wexels Riser C (2002) Seasonal and spatial changes in biomass, structure and the development progress of the zooplankton community in the Barents Sea. J Mar Syst 38:125-145

Castellani C, Robinson C, Smith T, Lampitt RS (2005) Temperature affects respiration rate of Oithona similis. Mar Ecol Prog Ser 285:129-135

Dam HG, Zhang X, Butler M, Roman MR (1995) Mesozooplankton grazing and metabolism at the equator in the central Pacific: Implications for carbon and nitrogen fluxes. Deep-Sea Res II 42:735-756

Drits AV, Semenova TN (1984) Experimental investigations of the feeding of Oithona similis Claus. Oceanologica 24: $755-759$

Edler L (1979) Recommendations for marine biological studies in the Baltic Sea; phytoplankton and chlorophyll. Baltic Marine Biologists, Vol 5, Gotab, Stockholm

Eilertsen HC, Schei B, Taasen JP (1981) Investigations on the plankton community of Balsfjorden, northern Norway: The phytoplankton 1976-1978. Abundance, species composition and succession. Sarsia 66:129-141

Feinberg LR, Dam HG (1998) Effects of diet on dimensions, density and sinking rates of fecal pellets of the copepod Acartia tonsa. Mar Ecol Prog Ser 175:87-96

Gonzáles HE, Smetacek V (1994) The possible role of the cyclopoid copepod Oithona in retarding vertical flux of zooplankton faecal material. Mar Ecol Prog Ser 113: 233-246

Gonzáles HE, Gonzáles SR, Brummer GJA (1994) Short-term sedimentation pattern of zooplankton, faeces and microplankton at a permanent station in the Bjørnafjorden (Norway) during April-May 1992. Mar Ecol Prog Ser 105: $31-45$

Green EP, Harris RP, Duncan A (1992) The production and ingestion of faecal pellets by nauplii of marine calanoid copepods. J Plankton Res 14:1631-1643

Guillard RRL, Ryther JH (1962) Studies on marine planktonic diatoms Cyclotella nana (Hustedt) and Detonula confervacea (Cleve) Gran. Can J Microbiol 8:229-239

Halvorsen E, Tande KS (1999) Physical and biological factors influencing the seasonal variation in distribution of zooplankton across the shelf at Nordvestbanken, northern Norway, 1994. Sarsia 84:279-292

Hansen BW, Fotel FL, Jensen NJ, Madsen SD (1996) Bacteria associated with a marine planktonic copepod in culture. II. Degradation of faecal pellets produced on a diatom, a nanoflagellate and a dinoflagellate diet. J Plankton Res 18:275-288

Holm-Hansen O, Riemann B (1978) Chlorophyll a determination: improvement in methodology. Oikos 30:438-447

Kiørboe T (2003) High turnover rates of copepod fecal pellets due to Noctiluca scintillans grazing. Mar Ecol Prog Ser 258:181-188 
Kiørboe T, Sabatini M (1994) Reproductive and life cycle strategies in egg-carrying cyclopoid and free-spawning calanoid copepods. J Plankton Res 16:1353-1366

Kiørboe T, Visser AW (1999) Predator and prey perception in copepods due to hydromechanical signals. Mar Ecol Prog Ser 179:81-95

Lampitt RS (1978) Carnivorous feeding by a small marine copepod. Limnol Oceanogr 23:1228-1231

Lampitt RS, Gamble JC (1982) Diet and respiration of the small planktonic marine copepod Oithona nana. Mar Biol 66:185-190

Lampitt RS, Noji TT, Bodungen BV (1990) What happens to fecal pellets? Implications for material flux. Mar Biol 104: $15-23$

Nakamura Y, Turner JT (1997) Predation and respiration by the small cyclopoid copepod Oithona similis: How important is feeding on ciliates and heterotrophic flagellates? J Plankton Res 19:1275-1288

Noji TT, Estep KW, Macintyre F, Norrbin F (1991) Image analysis of fecal material grazed upon by three species of copepods: Evidence for coprorhexy, coprorphagy and coprorchaly. J Mar Biol Assoc UK 71:465-480

Paffenhöfer GA (1993) On the ecology of marine cyclopoid copepods (Crustacea, Copepoda). J Plankton Res 15: $37-55$

Paffenhöfer GA, Mazzocchi MG (2002) On some aspects of the behaviour of Oithona plumifera (Copepod: Cyclopoida). J Plankton Res 24:129-135

Paffenhöfer GA, Strickland JDH (1970) A note on the feeding of Calanus helgolandicus on detritus. Mar Biol 5:97-99

Pasternak A, Arashkevich E, Wexels Riser C, Ratkova T, Wassmann P (2000) Seasonal variation in zooplankton and suspended faecal pellets in the subarctic fjord Balsfjorden, northern Norway, in 1996. Sarsia 85:439-452

Sampei M, Sasaki H, Hattori H, Fukuchi M, Hargrave BT (2004) Fate of sinking particles, especially faecal pellets, within the epipelagic zone in the North Water (NOW) polynya of northern Baffin Bay. Mar Ecol Prog Ser 278: $17-25$

Sasaki H, Nishizawa S (1981) Vertical flux profiles of particulate material in the sea off Sanriku. Mar Ecol Prog Ser 6: 191-201

Editorial responsibility: Otto Kinne (Editor-in-Chief), Oldendorf/Luhe, Germany
Small LF, Knauer GA, Tuel MD (1987) The role of sinking fecal pellets in stratified euphotic zones. Deep-Sea Res 34: 1705-7012

Smetacek V (1980) Zooplankton standing stock, copepod faecal pellets and particulate detritus in Kiel Bight. Estuar Coast Mar Sci 11:477-490

Suzuki H, Sasaki H, Fukuchi M (2003) Loss processes of sinking particles by mesopelagic copepods under the Antarctic marginal ice zone. J Oceanogr 59:809-818

Svensen C, Kiørboe T (2000) Remote prey detection in Oithona similis: hydromechanical vs. chemical cues. J Plankton Res 22:1155-1166

Svensen C, Nejstgaard JC (2003) Is sedimentation of copepod faecal pellets determined by cyclopoids? Evidence from enclosed ecosystems. J Plankton Res 25:917-926

Turner JT (2004) The importance of small planktonic copepods and their roles in pelagic marine food webs. Zool Studies 43:255-266

Urban-Rich J, Nordby E, Andreassen IJ, Wassmann P (1999) Contribution by mesozooplankton faecal pellets to the carbon flux on Nordvestbanken, North Norwegian shelf 1994. Sarsia 84:253-264

Utermöhl H (1931) Neue Wege in der quantitativen Erfassung des Planktons. (Mit besonderer Berücksichtigung des Ultraplanktons). Verh Int Verein Theor Angew Limnol 5: 567-596

Viitasalo M, Rosenberg M, Heiskanen A-S, Koski M (1999) Sedimentation of copepod fecal material in the coastal northern Baltic Sea: Where did all the pellets go? Limnol Oceanogr 44:1388-1399

Wassmann P (1998) Retention versus export food chains: processes controlling sinking loss from marine pelagic systems. Hydrobiologia 363:29-57

Wexels Riser C, Wassmann P, Olli K, Arashkevich E (2001) Production, retention and export of zooplankton faecal pellets on and off the Iberian Shelf, north-west Spain. Prog Oceanogr 51:423-441

Wexels Riser C, Wassmann P, Olli K, Pasternak A, Arashkevich $E$ (2002) Seasonal variation in production, retention and export of zooplankton faecal pellets in the marginal ice zone and the central Barents Sea. J Mar Syst 38: $175-188$

Submitted: February 8, 2005; Accepted: July 17, 2005

Proofs received from author(s): November 15, 2005 